\title{
ISAAC WALDRIP, CIRCUIT RIDER
}

\section{By Belle WALdRIP LUNT}

Isaac Waldrip, familiarly known in his later years as Father Waldrip, was a Methodist Circuit Rider. His courage and tenacity of purpose is exemplified by the persistence with which he broke away from his early Quaker training, and accepted the "call" to become the itinerant messenger of the gospel in what then seemed a wilderness, lying beyond the timbered hills of his native state, Virginia.

Isaac, like many others of his time, felt the restraint of his Quaker upbringing, and longed to get away and explore the unknown region to the west-a land of which so many rumors and exciting tales of adventure were constantly penetrating the secluded enclosure which was the only world he knew.

Being well schooled in obedience by his Quaker teachings, and, also, being very conscientious as to the homage due his parents and others in authority over him, he was only impelled by a stronger power within himself than any man-made precept-an urge that could not be denied, and must be vindicated at any cost. This inner strength enabled him to understand every argument, not in defiance, but as an earnest conviction that he must not yield to any one, however loved or revered.

He was born on the Virginia side of the Ohio river in 1813. Immediately following the second victorious war with Great Britain, Americans became imbued with a new self-confidence and sense of importance. They felt that now they could rightfully take their place among the nations of the world, and were now free to develop the powers of their people, and the natural and varied resources of a country greater than had ever yet been known. "Our old men dreamed dreams, and our young men saw visions," and they now determined to 
build for themselves and their posterity a land second to none and superior to all others.

True, the youth of this generation in this particular locality, were already grown restive, under the set "Rule of Thumb" of the Quaker religion. It was stirring times, and the land was full of adventure. There was not only beauty, but mystery-knowledge to be sought and obtained-life to be experienced and lived. No longer wiling to accept as final the rulings of another age, they were now wavering between the allegiance due the past, and the urge to push forward into the future. Quaker young people yearned to throw off the restraint that marked them as peculiar. They wanted to talk and dress and act as others with whom they came in contact.

As an example of the strict obedience required by the Quakers of that day, the story is related of Isaac's sister Hester, who had grown tired of the conventional drab of the Quaker form of dress, and longed for some dye stuff, that she might fashion something for herself in a brighter hue, more like that worn by other girls in her midst. Having no money of her own, and fearing her father would forbid such worldly frivolities should she ask him for the desired where-with-all, she was much concerned as to how she might procure the coveted dye. She finally hit upon a plan, and drew from the barrel some of her father's molasses, which she set aside to await the coming of the huckster. In the days that followed she felt troubled, and, at last, appealed to her mother, hoping for encouragement or permission to carry out her plan; but her mother very gravely replied: "Hester, if thy conscience condemn thee, thou hadst better put it back."

Isaac loved to sing. The Quaker training repressed this emotion, while the Methodists gave zest to it. The impulse to sing loud and long could not be quieted, so he was found often in the meeting house not of his early training. One night, when they had gathered in the meeting house, a storm came on, and they were forced to remain all night. They spent the time in 
singing and praying, exhorting and preaching; with occasional intermissions when they played "Who's got: the button?" Toward morning of this never to be forgotten night, Isaac professed to have received the call to preach. In this he was ridiculed by his cousin, who tried to convince him it was only neighbor Jenkins calling his hogs. However, Isaac was not to be diverted from his earnest conviction, and from this time on, never wavered from what he accepted as his life work.

\section{ENTERED His LIFE's MiNisTRY}

It was a well confirmed precept among Quakers that no man should be a parasite, but that every one should earn his living with his own hands. The gift of the spirit was free-God-given-and no man should accept pay for dispensing it. As did Paul of old, so must every bearer of the gospel now, work at his trade for a livelihood. The very nature of the country in southern Ohio and the neighboring hills of Virginia and West Virginia had determined the manner of subsistence. It was a timbered land; so, the felling of trees, the sawing of lumber, the building of homes, mills, dams and bridges was a leading industry. In all these things young Isaac had become proficient; so, it was with an undaunted spirit that, when but nineteen years of age, he set forth on his own. Characteristically, he avoided the larger, more thrifty settlements, and sought out the backward, less favored ones, as being more needful of his ministrations. His first location was a small river town not far from Attica, Indiana, where he met and married the beautiful sixteen-year-old Marian Underwood, in 1832, before he, himself had attained to the age of twenty. Here the young preacher worked in the mill in the winter, and in summer, built houses and bridges of the logs that had been sawed. Sundays and night, he preached and sang his way into the hearts of his fellow workers. They remained here for some time, and Isaac continued to work and preach and sing, and to study nights, mostly by the light of the big log in the fireplace. Marian made tallow 
candles to read by in the meeting house, but tallow was scarce and much too hard to obtain to be extravagantly used in the home-a grease dip in a saucer proving sufficient supplement to the fireplace for all their simple needs.

While here, Isaac was ordained as a minister and commissioned, with a small band, to push on to the shores of Lake Michigan.

Isaac and Marian were now on their way. They literally burned their bridges' behind them, if indeed there were any, as together they set their faces forward to the westward; always going forward, and, as it so happened neither was ever again to see or set foot upon the land of their birth and upbringing.

Much to their satisfaction, it was their privilege to assist in the building and developing of Fort Dearborn, which later became Chicago. The Waldrips lived in Fort Dearborn long enough to acquire land in their own right. Here, also, two of their eight children were born, and buried. In time, however, this life became prosaic, Isaac longed for new fields and a wider scope, and as he gazed westward, something seemed to beckon him to "Go forward." Finally, he applied for, and obtained a commission to establish missions in the territory now comprising the four states, Illinois, Iowa, Missouri and Nebraska. In response to this trust, not even waiting to dispose of his landed possessions, he again took the trail.

Some time later, he located in a small place some hundred miles to the south in Sangamon county, Illinois, where a thriving religious work soon flourished. At this place, a son Isaac, was born and not buried. Realizing that life, at best, is short, and that a large and difficult territory awaited his come and considering two thriving fields to be a fair proportionate share for Illinois at the present, he began to cast longing eyes across the Mississippi, and around the year 1840, crossed over into Iowa. 
Finding Protestant missions already established along. the river towns, he, without identifying himself with any conference, if indeed there were any at that time, pushed on to the south and westward, stopping here and there wherever his services seemed most needed; and, too, where he might find means of subsistence at his early acquired trade of mill and bridge building. He lived for a time in Memphis, Missouri, where, in 1845, a daughter, Martha, was born.

Leaving his family at home, he toured the surrounding territory, in both Iowa and Missouri, on horseback, distributing tracts and copies of the gospels, which he carried in leather bags suspended from his saddle. Later, the family moved over into Scuyler county, where they lived at the time of the breaking out of war with Mexico. Quite un-Quaker-like, Isaac became actively engaged in war work and was away in the interest of the government and the army at the time his son, Byron, was: born, which occurred on the very day the battle of Buena. Vista was fought.

\section{IN IOWA AND Missouri FieldS}

Later, when relieved of these activities, he again took up residence in Iowa, living for some time in Eddyville. By this time the Southern Iowa conference had been organized, to which he was admitted at Fairfield, in 1850. The same year, at his own request, he was transferred to the Missouri conference, and assigned to the Princeton mission. Taking up his abode in Tennessee Ford, he rode the surrounding circuit, making regular trips to Ravanna, Trenton, Chillicothe, Bethany, Cainsville, Maryville, and Plattsburg, in Missouri, and Lineville and Pleasanton in Iowa; to say nothing of the many overnight stops in this wide itinerary, where it was his: custom to rally a crowd to whom he exhorted, passed out tracts and copies of hymns, which they lustily joined him in singing. If the printed copies of hymns were scarce, as frequently happened, he read two lines, which they sang, then two more, and so on till the entire hymn had: 
been sung. It is surprisingly wonderful how quickly these songs were learned, both words and music. Who can doubt their influence? Long after the minister had passed on to other fields, the songs remained, bringing joy to the young and comfort to the old.

All the time the loved pastor was riding this circuit, he did not cease to build bridges, saw mills and grist mills. Some of them, he operated too, producing much of the lumber that went into construction of homes and barns that otherwise could not have been built until a much later date. Among mills that he built and operated for a time, was one at Trenton, Missouri, and another at Haymaker Ford. One at Bethany, Missouri, still stands (1935), although no longer used as a mill. The Colonel Wright flour and grist mill at Lineville was also the work of his brain and hands.

While living in this vicinity, his son Isaac, although a very young boy, attended the Grand River college at Trenton.

As his work progressed, Father Waldrip, as he now began to be called, with still his first great commission on his conscience, moved gradually westward, living for a while in Cainsville, then, in Chillicothe, Missouri. Up to that time all had gone well. Because of his early strenuous labors, and accompanying thrift, he no longer felt so keenly the pinch of poverty, nor did it seem necessary to continue so actively in the struggle for bread. Others could capably assume this part of the program, and leave him more freedom for other things. He now entered freely and enthusiastically into the recreations and pastimes of the community. Whatever interested other men, also interested him.

Once he so far unbent as to take Martha and Byron to the circus. They followed the parade into the show grounds; watched the bespangled ladies dismount and disappear into the tent; thrilled to the piping airs of the steam calliope; then, made the rounds of the animal tent, viewing with wonder the elephants, the giraffe and the zebra. However, it was not seemly that one of 
his calling should actually watch the performance; so, much to the chagrin and disappointment of the children, and perhaps to himself as well, he dutifully led them outside the gates before the hour set for the real circus to begin. The self-denial entailed by this religiously imposed duty can only be appreciated by a survey of the dearth of entertainment and the paucity of recreations of his day.

\section{Racial Rift Causes Removal}

The strong and sturdy uprightness of the man won for him the admiration and confidence of the entire community. None could doubt his integrity, and all held him in high esteem. But, alas, here, in Chillicothe, he was to know perhaps for the first time in his life; the bitterness of prejudice-the cruel sting of unpopularity. The question of slavery was much agitated at this time, and Missouri was a sort of borderland between slave and free. There were many negroes in Chillicothe and vicinity, and Father Waldrip not only aided them, but spoke fearlessly in their defense, and against the institutions that held them in bondage. Soon dissension arose, and many took sides against him. Martha, sitting on a doorstep at a quilting, overheard the women talking and heard one of them say: "I do wish Father Waldrip would not be so outspoken and say so much, for I fear harm will come to him and I would not have one hair of his head harmed."

However, when it became known that Martha and Byron had taught Abigail, a colored girl working at the mill, to read, indignation ran high, and the minister was waited upon by a committee demanding that he forbear these abolitionist activities. Still he persisted in adhering to his principles because he believed they were right, and no man should or could prevent him from proclaiming the truth as he saw it. Opposition continued until finally he was forced to resign; and, under dire threats, advised to leave the country. 
This seemed to have been a purely local controversy. There is no record of his ever having been expelled from the conference, or even called before that body for examination or questioning. . Yet, he felt deeply humiliated and grieved that the very people he loved and trusted most could be so unfair as to deny him the right of free speech, which, as he saw it, was the only accusation brought against him. Sorrowfully, he removed to Pleasanton, Iowa.

As yet, the Nebraska territory remained untouched. Desiring to at least accomplish something toward the fulfilling of this part of his contract, he now began to consider, seriously, the possibilities across the Missouri. Fearing to leave his family to the uncertain mercies of a disturbed and fast becoming belligerant populace, he fitted a covered wagon for travel that they might accompany him. Together they journeyed westward, on the far side of the Missouri, finally settling in Beatrice, Nebraska, then a small village of a few whites and many Indians. This was the nucleus, from which he hoped to extend his work into the surrounding country. By now, the all-enduring Marian had grown tired of roving and pioneering, and she was so desperately afraid of the Indians that her health suffered; so, after a little more than a year in Beatrice, they, in 1860, returned to Pleasanton, and, for the time being, Father Waldrip gave up the strenuous life of lumbering, and settled down to the keeping of a general dry goods store. About this time young Isaac was married, and soon after, with his courageous young wife, joined a caravan to the great northwest. Neither was destined ever again to look upon the face of loved ones left behind. On this pilgrimage hangs another tale of the house of Waldrip.

Though stern and unrelenting in the vigor with which he persued the righteous path of duty, as he saw it, Father Waldrip could yet relax into the jovial good fellowship of his countrymen, and enter into their enterprises with such boyish enthusiasm, as to add greatly to the enjoyment of any occasion, whether it be a simple 
picnic or the celebration of some local or great national event. The Fourth of July was to him a day calling for his best efforts, in thought, energy, time and money; that the celebration might be in some way worthy of the great event it commemorated. No doubt, his participation prevented many a weaker man from imbibing too freely, and thus ending in debauchery what should be. a glorious day. Typical of Father Waldrip was that he never got far away from his religious thought, and more often than not, at the close of a jollification, he started a hymn in which all joined in singing, thus parting company in the general good fellowship that did not. exclude the Great Giver of all good gifts. He knew of no better way of bringing to a close the day's activities, than the introduction of a community sing, in which everybody's favorite was sung.

\section{SON ENLISTS IN NORTHERN ARMY}

Following the declaration of the Civil war, Martha was sent to what was then called the "Blue Bird" college at Indianola, Iowa. Byron, a stripling of fifteen, enlisted in the army. His father equipped him with his own horse and saddle in order that he might serve in the cavalry, fearing Byron was too young and tender to endure the hardships of the infantry.

This is but another proof of how far Father Waldrip had divorced himself from the precepts of his early training in the Quaker religion. He loved his country, and what he loved, he willingly sacrificed and fought for, even to the point of laying down his life if need be. He should have esteemed himself unworthy, had he failed to give fearlessly of his best, physically, mentally and spiritually for the cause he believed was just and right. The hardships of life had aged him beyond his years, and the venerable, gray-bearded old man was not accounted eligible for service in the army, so he had to content himself with ministering to the wants of those who were left behind; and with aiding the recruiting officers by strengthening the morale of the men enlisted 
for service. The story is told of him making a supper for the boys, about seventy-five in number, furloughed home for a brief stay, following their re-enlistment for the duration of the war. He lived in a three-room house, but undaunted, and not to be deterred by so small an obstacle, he erected tables outside and Marian, with the help of one woman, prepared the entire feast consisting of wild turkey, squirrel, vegetables, cakes and pies, with a mixed cereal-and-crust coffee and lemonade.

At the close of the war, when Byron had returned and married, they gave up the store at Pleasanton, and went back to the Haymaker Mill farm, still in their possession. Here they sawed the timber, except the finish and shingles, for a house for Byron. However, they now traded the mill and timber land for a farm within three miles of Lineville, so the buildings were erected on this new location.

It would seem that his Lineville friends were still fond of Father Waldrip. There was a vacancy in their church, and they urged him to move into town and preach for them. Unable to resist their entreaties, leaving Byron on the farm, he moved into town and built for himself another new home. Presently, however, he began to realize that his energy was expended. He felt weary and prematurely old, so he begged to be relieved and again retired to the farm,; where he busied himself with his orchard, experimenting in grafting fruits, etc., occasionally preaching in Lineville or some neighborhood school house. Nothing delighted him more than the summer camp meetings. People came from miles around to attend them. In addition to the gospel dispensed, they served as a social outlet and recreation center, refreshing and, no doubt, renewing to many a lagging spirit.

In connection with these camp meetings, often lasting for as long as six weeks, we would not overlook the oneday basket meetings. Many people who could not leave their homes and employments for the longer session of the camp meeting, could yet fill their baskets, rise early, don their best clothes, and drive in the cool morning 
hours to some distant grove or river bank, where they were treated to at least two inspiring religious services, in addition to the enjoyment of mingling with friends for a few hours. Then, too, there was the sharing of the good things in the baskets. All of these gatherings were pure joy to the simple, benevolent soul of Father Waldrip.

The quiet restful days on the farm, in time seemed to bring back something of the old time vigor, and again Isaac grew restless.

He had heard of the country opening up in the Dakotas, and his soul yearned for Yankton. He felt this settlement must need a mill and, most of all, the settlers needed the gospel. After much deliberation, and due consideration, he again succumbed to the inexorable urge, rented the farm, made a sale, and prepared for the long trek to Dakota.

This plan was frustrated by his untimely death. He was suddenly taken ill with pneumonia, and died at the age of fifty-eight.

He had preached his last sermon in Lineville, and some years later, when the little old church gave way to a more imposing one, it was the pleasure of Byron, assisted by the life-long friend, Dr. E. Glendenning, to place in their memory, in this new edifice, a window bearing the names of both Isaac and Marian Waldrip.

His remains were carried back to Pleasanton and placed in the family plot in the North graveyard, as the cemetery was then called. Here, two of his children already were buried. But three, Isaac, Martha and Byron, of their eight children, lived to attain to the years of full maturity. Many years later the body of the gentle Marian was taken back and laid by his side.

The "Great Beyond" is to them no longer a mystery; no longer a land to be explored and conquered; but the Home of which they had so often dreamed and sang. 
Copyright of Annals of Iowa is the property of State of Iowa, by \& through the State Historical Society of Iowa and its content may not be copied or emailed to multiple sites or posted to a listserv without the copyright holder's express written permission. However, users may print, download, or email articles for individual use. 